\title{
PENGARUH HEALTY LIFESTYLE, PSYCHOLOGICAL WELL BEING, DAN SELF EFFICACY TERHADAP KINERJA AUDITOR DENGAN TASK COMPLEXITY SEBAGAI PEMODERASI
}

\author{
Fahrun Rijal \\ fahrunrijal19@gmail.com \\ FEBI UIN Alauddin Makassar \\ Muhammad Wahyuddin Abdullah \\ tosir_wahyu@yahoo.com \\ FEBI UIN Alauddin Makassar
}

\begin{abstract}
Abstrak
Abstrak:Tujuan penelitian ini adalah untuk mengetahui pengaruh masing-masing variabel healty lifestyle, psychological well being, dan self efficacy terhadap kinerja auditor. selain itu, penelitian ini juga bertujuan untuk mengetahui pengaruh varaibel task complexity dalam memoderasi hubungan antara variabel independenndengan kinerja auditor. Penelitian ini merupakan penelitian kuantitatif. Populasi dalam penelitian ini adalah auditor yang bekerja di kantor Inspektorat provinsi Sulawesi Selatan. Teknik pengambilan sampel menggunkan metode random sampling dengan total sampel sebanyak 31 orang responden. Data yang digunakan dalam penelitian ini merupakan data primer dengan membagikan kuesioner untuk para responden di Inspektorat provinsi Sulawesi Selatan.Metode analisis data yang digunakan dalam penelitian ini adalah metode regresi berganda.

Hasil penelitian menunjukkan bahwa healty lifestyle dan self efficacy berpengaruh positif dan signifikan terhadap kinerja auditor Sedangkan psychological well being tidak berpengaruh terhadap kinerja auditor. Hasil penelitian terkait variabel moderasi menunjukkan bahwa task complexity mapu memoderasi healty lifestyle terhadap kinerja auditor. Namun, variabel task complexity tidak mapu memoderasi hubungan antara psychological well being dan self efficacy terhadap kinerja auditor.

Implikasi dari penelitian ini adalah pentingnya bagi para auditor untuk senantiasa menjaga pola hidup sehat yang baik dan juga selalu memiliki kepercayaan diri yang tinggi dalam menjalankan tugasnya sebagai pemeriksa. Pola hidup sehat yang baik akan berdampak pada kesiapan auditor dalam menjalankan penugasan auditnya, sementara kepercayaan diri yang tinggi mampu memberikan motivasi bagi auditor untuk bekerja dengan optimal.
\end{abstract}

Kata Kunci: Healty lifestyle, psychological,task complexity. 
Abstract: The research aims to know the effect of healty lifestyle, psychological well being,, and self efficacy to auditor performance. This research also wants to determine the effect of task complexity as moderating variable between the independen variable and auditor performance. This study is a qualitative research. Population of this research is auditor who working on Inspectorate of South Sulawesi. Random sampling method has been aplied with 31 respondents. This research using the primary data by sharing questionnaires to respondents. The data analysis using multiple regression method.

The results show that healty lifestyle, and self efficacy had a positive and significant effect on the auditor performance while the psychological well being had no effect on the auditor performance. In the other side, the task complexity as moderating variable show that a map to the healty lifestyle on the auditor performances. However, the task complexity disable to moderate relation between psychological well being and self efficacy on auditor performance. This research show the implication about how important to keep the healty lifestyle for auditors and then the important to keep their confidence to carrying out their duties. The good lifestylewill hiring the auditors to have a good impact in carrying out their assignments, while high self-esteem can motivate the auditor optimally.

\section{Keywords: healty lifestyle, psychological, task complexity.}

\section{Pendahuluan}

Laporan keuangan menyediakan berbagai informasi mengenai gambaran kinerja perusahaan yang digunakan oleh pengguna laporan keuangan baik pihak internal maupun pihak eksternal perusahaan.Laporan keuangan merupakan bentuk pertanggungjawaban manajemen yang berupa asersi (representasi) baik secara eksplisit ataupun implisit. Laporan keuangan adalah ringkasan atas proses pencatatan dari transaksi-transaksi keuangan yang terjadi selama periode berjalan (Futri dan Juliarsa, 2014). Menurut FASB, karakteristik terpenting yang harus ada dalam laporan keuangan mencakup dua hal yakni relevan (relevance) dan dapat diandalkan (reliable). Kedua karakteristik tersebut sangatlah sulit untuk diukur, sehingga para pemakai informasi membutuhkan jasa pihak ketiga yaitu auditor independen untuk memberi jaminan bahwa laporan keuangan tersebut memang relevan dan dapat diandalkan serta dapat meningkatkan kepercayaan semua pihak yang berkepentingan dengan perusahaan tersebut (Singgih dan Bawono, 2010).

Kinerja auditor sangat dibutuhkan oleh para pengambil keputusan agar tidak salah dalam mengambil tindakan.Trisaningsih (2007) menyatakan kinerja atau prestasi kerja adalah suatu hasil karya yang dicapai oleh seseorang dalam melaksanakan tugas-tugas yang dibebankan kepadanya yang didasarkan atas kecakapan, pengalaman, dan kesungguhan waktu yang diukur dengan mempertimbangkan kuantitas, kualitas, dan juga ketepatan waktu.Kinerja auditor merupakan hasil yang dicapai oleh auditor dalam pelaksanaan tugasnya, dan menjadi tolak ukur dalam menentukan benar baik atau buruknya hasil kerja seorang auditor (Hanif, 2013).Oleh karena vitalnya peran auditor sebagai pihak ketiga yang memeriksa kebenaran informasi yang diberikan oleh perusahaan maka auditor dituntut untuk memberikan kinerja yang baik dalam setiap penugasan yang diterimanya. Opini yang dikeluarkan oleh auditor 
sangat menentukan penilaian pihak-pihak pengguna laporan keuangan dalam menentukan tindakan yang akan diambil.

Dalam akuntansi dikenal dua macam kesalahan yakni kekeliruan (error) atau kecurangan (fraud) (Yurmaini, 2017).Perbedaaan di antara kekeliruan dan kecurangan sangat tipis yakni terletak pada niat pelaku.Kekeliruan atau error merupakan kesalahan yang dilakukan oleh auditor dalam pelaksanaan auditnya tanpa adanya unsur kesengajaan. Sementara kecurangan atau fraud adalah tindakan tidak etis yang dilakukan oleh auditor dengan sengaja untuk memperoleh keuntungan pribadi atau kelompok yang berpotensi merugikan pihak lain.Sayyid (2015) menyatakan bahwa fraud atau kecurangan adalah berbagai macam carakecerdikan manusia yang direncanakan dan dilakukan secara individual maupun berkelompok untuk memperoleh manfaat atau keuntungan dari pihak lain dengan cara yang tidak benarsehingga menimbulkan kerugian bagi pihak lain.

Faktor yangdisinyalir dapat menyebabkan kecurangan(fraud) adalah kurangnya moralitas dan juga spiritual yang dimiliki seorang individu. Hasil penelitian Wilopo (2006) menunjukkan semakin tinggi level penalaran moral individu cenderung membuatnya tidak melakukan kecurangan akuntansi. Demikian juga penelitian dari Wicaksono dan Urumsah (2016) telah membuktikan bahwa individu yang memiliki tingkat keimanan yang baik cenderung untuk menghindari kecurangan.Orang yang memiliki tingkatan spiritual yang tinggi cenderung untuk melakukan hal-hal positif yang tidak bertentangan dengan ajaran agama.Selain kecurangan, dalam kegiatan pengauditan kesalahan juga dapat berupa kekeliruan atau error.Berbeda halnya dengan kecurangan, jika kecurangan didasarkan pada lemahnya moralitas dan tingkat spiritual yang dimiliki oleh auditor, maka kekeliruan disebabkan oleh faktor kurangnya ketelitian ataupun pengetahuan dari pelakunya.Ada berbagai macam faktor yang dapat menyebabkan kekeliruan bisa terjadi diantaranya adalah kebiasaan, pola pikir, dan motivasi.Faktor yang diduga mempengaruhi kinerja auditor yang pertama adalah gaya hidup sehat (healty lifestyle). Danna dan griffin (1999) mengartikan gaya hidup sehat atau healty lifestyle merupakan kebiasaan menjaga program olahraga fisik secara teratur, menjalankan diet seimbang, kebiasaan tidur yang baik, dan menahan diri dari konsumsi alkohol dan tembakau yang berlebihan. Penerapan gaya hidup sehat dapat berpengaruh pada kebugaran yang dimiliki oleh seorang auditor yang dapat berpotensi pada peningkatan konsentrasi dalam mengerjakan penugasan auditnya.

Faktor lain yang diduga dapat mempengaruhi kinerja auditor adalah kesejahteraan secara psikologi atau Psycholological well being. Merupakan kondisi mental individu yang memiliki sikpa positif terhadap diri sendiri dan orang lain. Sikap positif tersebut ditandai dengan adanya kemampuan membuat keputusan sendiri dan mengatur tingkah lakunya. Individu yang bersangkutan juga dapat menciptakan dan mengatur lingkungan yang sesuai dengan kebutuhannya, memiliki tujuan hidup dan membuat hidup lebih bermakna, serta berusaha mengeksplorasi dan mengembangkan dirinya (Ryff , 1995). Dengan memiliki tingkatan kesejahteraan psikologi yang baik maka individu dapat bekerja dengan maksimal karena kesejahteraan psikologi akan membuatnya lebih nyaman dalam bekerja serta tidak mengalami stres atau depresi yang diakibatkan oleh tugas yang kompleks. Oleh karena itu, 
dengan memiliki tingkat kesejahteraan psikologi yang baik akan mempengaruhi peningkatan kinerja seorang auditor.

Faktor self efficacy juga disinyalir memiliki keterkaitan dengan peningkatan kinerja auditor.Suprapta dan Setiawan (2017) menyatakan bahwa self efficacy merupakan kepercayaan seseorang terhadap kemampuannya untuk dapat melaksanakan tugas dengan baik. Individu yang memiliki tingkat self efficacy yang tinggi akan memiliki keyakinan dalam menjalankan tanggung jawab yang diembannya meskipun dalam kondisi yang sulit ataupun terdapat konflik peran didalamnya sehingga individu yang bersangkutan memiliki peluang keberhasilan yang lebih tinggi dibandingkan dengan orang yang pesimis terhadap pekerjaannya atau dalam hal ini memiliki nilai yang rendah dalam aspek self efficacy. Dengan demikian, individu yang memiliki tingkatan self efficacyyang tinggi akan berpengaruh pada peningkatan kinerjanya dikarenakan self efficacy dapat memberikan motivasi akan keberhasilan tugasnya. Hal ini sejalan dengan hasil penelitian dari Kristianti (2015) yamg menyatakan bahwa self efficacymemiliki pengaruh positif terhadap kinerja auditor.Auditor yang memiliki kepercayaan diri yang tinggi akan dapat mengembangkan kepribadian yang kuat, mengurangi stress, tidak mudah terpengaruh sehingga berpengaruh terhadap peningkatan kinerjanya.

Berdasarkan pembahasan di atasmengenai berbagai macam faktor yang dapat meningkatkan kinerja auditor, peneliti tertarik menemukan faktor-faktor yang dapat meningkatkan kinerja auditor di Inspektorat sehingga dapat meminimalisir adanya kekeliruan yang terjadi saat penugasan auditnya, serta dampak dari kompleksitas tugas terhadap faktorfaktor tersebut.Penelitian mengenai mekanisme yang dapat dilakukan dalam upaya menjaga kinerja auditor telah banyak dilakukan oleh penelitian sebelumnya. Pada penelitian ini akan mencoba menguji kembali faktor-faktor tersebut dengan menambahkan variabel task complexity sebagai pemoderasi. Hal ini dikarenakan, task complexity diduga memiliki pengaruh dalam memperkuat atau memperlemah pengaruh faktor-faktor tersebut terhadap kinerja auditor.Dalam penelitian ini, peneliti akan mengkaji hubungan antara faktor kebiasaan gaya hidup sehat, kesejahteraan psikologi, serta efikasi diri terhadap peningkatan kinerja auditor yang dimoderasi oleh kompleksitas tugas.

\section{Tinjauan Pustaka}

\subsection{Expectancy Theory}

Teori pengharapan (expectancy theory) pertama kali diperkenalkan oleh Victor Vroom pada tahun 1964. Teori ini menyatakan bahwa intensitas cenderung melakukan sesuatu dengan harapan bahwa kinerja akan diikuti dengan hasil yang pasti dan daya tarik setiap individu. Pada teori motivasi kerja ini ditekankan pada proses yang terjadi mulai dari timbulnya kebutuhan sampai terciptanya tujuan dan penghargaan yang diinginkan (Utami dan Triani, 2015). Seseorang dengan motivasi yang kuat untuk mencapai tujuannya akan berdampak positif terhadap keberhasilannya, begitu juga sebaliknya apabila seseorang tidak memiliki motivasi yang kuat maka akan berdampak negatif terhadap keberhasilannya. Auditor yang memiliki motivasi yang kuat untuk memeriksa laporan keuangan dengan optimal akan 
berdampak positif dalam keberhasilannya untuk menghasilkan opini yang tepat terhadap laporan keuangan yang diauditnya.

\subsection{Atribution Theory}

Teori atribusi atau attribution theory pertama kali diperkenalkan oleh Harold Kelley pada tahun 1972.Secara garis besar teori atribusi menggambarkan alasan seseorang memilih suatu tindakan dalam upaya untuk mengatasi masalah yang dihadapi. Teori atribusi adalah teori yang menjelaskan upaya untuk memahami penyebab dibalik perilaku orang lain (Rahmi dan Sofia, 2017). Teori ini menggambarkan mengapa individu memilih untuk menggunkanan suatu tindakan tertentu sebagai upaya dalam menghadapi suatu situasi atau persoalan yang sedang dialami. Teori ini dapat menggambarkan alasan pemilihan sikap seorang auditor dalam menghadapi setiap situasi yang dihadapi. Sebagai contoh, alasan mengapa auditor memilih menggunakan waktu luang yang dimilikinya untuk melakukan pelatihan profesi dibandingkan menggunakan waktu luangnya untuk berlibur.

\subsection{Healty Lifestyle}

Danna dan Griffin (1999) mengartikan gaya hidup sehat atau healty lifestyle merupakan kebiasaan menjaga program olahraga fisik secara teratur, menjalankan diet seimbang, kebiasaan tidur yang baik, dan menahan diri dari konsumsi alkohol dan tembakau yang berlebihan.Individu yang memiliki mekanisme gaya hidup sehat cenderung memiliki ketahanan fisik dan psikis yang baik dibandingkan dengan individu yang tidak menerapkan gaya hidup sehat dalam kehidupan sehari-harinya sehingga dapat meminimalisir stress kerja yang ada. Dengan demikian, penerapan gaya hidup sehat dapat menjadikan auditor lebih baik dari segi kesehatan dan juga memperoleh kebugaran yang prima sehingga berpengaruh pada kinerja yang baik pula.

\subsection{Pshychological Well Being}

Psychological well being adalah sebuah kondisi individu yang memiliki sikap positif terhadap dirinya sendiri dan orang lain yang ditandai dengan adanya kemampuan membuat keputusan sendiri dan mengatur tingkah lakunya, menciptakan dan mengatur lingkungan yang sesuai dengan kebutuhannya, memiliki tujuan hidup dan membuat hidup lebih bermakna, serta berusaha mengeksplorasi dan mengembangkan dirinya (Ryff, 1995). Psikologi yang baik akan menimbulkan efek positif terhadap perasaan auditor dalam melaksanakan penugasan auditnya. Kesejahteraan psikologi yang dimiliki oleh auditor akan menuntun pada kenyamanan dan motivasi dalam bekerja sehingga hasil kerjanya akan optimal.

Ryff (1995) memaparkan enam dimensi psychological well being sebagai berikut:

1. Penerimaan diri/self acceptance, merupakan sikap positif yang dapat menerima semua hal yang menyangkut dirinya baik yang bersifat baik ataupun buruk. Individu yang memiliki sifat self acceptance senantiasa menerima segala kondisi buruk yang menimpanya dan berusaha bersabar dan berfikir positif untuk memperbaiki masa lalunya.

2. Relasi positif dengan orang lain/positive relations with others, merupakan sikap individu yang senantiasa menerima orang lain dengan baik, akan memiliki hubungan yang hangat, saling menghargai dan mempercayai sesama manusia, memperhatikan kesejahteraan orang lain daripada mementingkan egoisme sendiri, memiliki sikap tenggang rasa dan empati terhadap orang lain, dan hubungan timbal balik lainnya dengan orang lain. 
3. Autonomi/autonomy, merupakan kemampuan untuk mengarahkan diri sendiri, mandiri, dan mampu mengatur tingkah laku. Individu yang memiliki nilai tinggi pada dimensi ini akan selalu menjaga independensinya dan memiliki kepercayaan diri untuk mengemban amanah yang diterima, mampu mengatasi tekanan sosial, tidak tergantung pada pendapat orang lain, memiliki prinsip dan komitmen untuk menjadikannya lebih bertanggung jawab, selalu mengevaluiasi diri (bermuhasabah) terhadap apa yang telah ia lakukan, serta dapat berperilaku mandiri.

4. Penguasaan lingkungan/environmental mastery, merupakan kemampuan individu untuk memilih lingkungan kerja sesuai dengan kemampuannya. Individu yang memiliki nilai tinggi dalam dimensi ini memiliki wewenang untuk mengatur ataupun menata lingkungannya sendiri, mengatur urusan eksternal yang kompleks, serta mampu menciptakan konsep sesuai dengan target yang di inginkan dengan mengoptimalkan peluang yang ada.

5. Tujuan hidup/purpose in life, merupakan kemampuan individu untuk menentukan tujuan hidupnya. Individu yang memiliki nilai tinggi pada dimensi ini memiliki arah dan tujuan hidup sehingga ia akan senantiasa mempertimbangkan segala sesuatu yang dapat berdampak negatif bagi keberlangsungan hidupnya.

6. Pertumbuhan pribadi/personal growth, merupakan kemampuan individu untuk mengembangkan potensi dalam dirinya dan berkembang sebagai manusia berkelanjutan. Individu yang memiliki nilai tinggi pada dimensi ini maka akan merasa ada perkembangan potensi diri yang berkelanjutan, menyadari potensi diri dan melihat kemajuan dari waktu ke waktu, serta terbuka pada pengalaman baru.

\subsection{Self efficacy}

Rimper dan Kawet (2014) menyatakan bahwa efikasi diri merupakan salah satu aspek pengetahuan tentang diri atau self knowledge yang paling berpengaruh dalam kehidupan manusia sehari-hari karena efikasi diri yang dimiliki ikut mempengaruhi individu dalam menentukan tindakan yang akan dilakukan untuk mencapai suatu tujuan, termasuk didalamnya perkiraan terhadap tantangan yang akan dihadapi. Suprapta dan Setiawan (2017) menyatakan bahwa self efficacy merupakan kepercayaan seseorang terhadap kemampuannya untuk dapat melaksanakan tugas dengan baik. Individu yang memiliki tingkat self efficacy yang tinggi akan memiliki keyakinan dalam menjalankan tanggung jawab yang diembannya meskipun dalam kondisi yang sulit ataupun terdapat konflik peran didalamnya sehingga individu yang bersangkutan memiliki peluang keberhasilan yang lebih tinggi dibandingkan dengan orang yang pesimis terhadap pekerjaannya atau dalam hal ini memiliki nilai yang rendah dalam aspek self efficacy.

\subsection{Task Complexity}

Kompleksitas audit adalah persepsi individutentang kesulitan tugas audit yang disebabkan oleh terbatasnya kapasitas dan dayaingat serta kemampuan untuk mengintegrasikan masalah yang dimiliki. Persepsiini yang menimbulkan pemikiran dan kemungkinan bahwa tugas audit sulit bagiseseorang, namun mungkin mudah bagi orang lain (Restuningdiah dan Indriantoro, 2000). Dengan demikian, penilaian akan kompleksitas tugas akan bervariasi tergantung pada kapabilitas individu, daya ingat, dan juga kemampuan dalam 
mengintegrasikan masalah yang dimilikinya. Sebagian orang akan menganggap tugas audit sebagai tugas dengan kompleksitas tinggi dan sulit, dan sebagian lainnya menganggap tugas audit sebagai tugas yang relatif mudah untuk dikerjakan.

Kompleksitas audit dapat berdampak pada peningkatan ataupun penurunan kinerja auditor. Individu yang memiliki kompetensi yang baik dan didukung oleh kepercayaan diri yang tinggi dalam menyelesaikan suatu penugasan dapat berdampak positif dalam meningkatkan kualitas auditor dalam mengatasi masalah yang ada.Namun, kompleksitas tugas yang tinggi juga dapat berpengaruh negatif terhadap kinerja auditor ketika kompetensi yang dimiliki oleh auditor tidak sebanding dengan tingginya kompleksitas tugas yang diterima.Kondisi ini dapat membuat seorang auditor berperilaku disfungsional, dimana saat semakin banyak dan sulitnya tugas yang dia dapat membuat dirinya melewatkan beberapa tugas atau mengerjakan tugas tersebut secara tidak maksimal sehingga kinerjanya menjadi menurun.

\subsection{Kinerja Auditor}

Secara etimologi, kinerja berasal dari kata performance yang berarti prestasi kerja.Trisaningsih (2007) menyatakan kinerja auditor adalah suatu hasil karya yang dicapai oleh seseorang dalam melaksanakan tugas-tugas yang dibebankan kepadanya yang didasarkan atas kecakapan, pengalaman, dan kesungguhan waktu yang diukur dengan mempertimbangkan kuantitas, kualitas, dan ketepatan waktu.Kinerja auditor adalah pencapaian oleh auditor dalam melaksanakan penugasan auditnya yang berupa pemeriksaan (examination) terhadap laporan keuangan berdasarkan standar pemeriksaan yang berlaku. Kinerja auditor dapat dilihat dari opini yang dibuat oleh auditor yang merupakan hasil penilaian atau judgment auditor yang didasarkan pada standar pemeriksaan audit yang berlaku dengan memperhatikan kualitas, kuantitas, dan ketepatwaktuan dalam pelaporan auditnya.

\subsection{Hipotesis Penelitian}

\section{Pengaruh Healty Lifestyle terhadap Kinerja Auditor}

Danna dan Griffin (1999) mengartikan gaya hidup sehat atau healty lifestyle merupakan kebiasaan menjaga program olahraga fisik secara teratur, menjalankan diet seimbang, kebiasaan tidur yang baik, dan menahan diri dari konsumsi alkohol dan tembakau yang berlebihan. Dengan menerapkan gaya hidup sehat yang baik akan menambah kebugaran dan mengurangi stres yang diterima dalam menjalankan tugas sebagai seorang auditor sehingga akan berdampak pada peningkatan kinerja yang dimilikinya. Adapun hipotesisnya sebagai berikut:

H1: Healty Lifestyle berpengaruh positif terhadap kinerja auditor.

\section{Pengaruh Psychological Well Being terhadap Kinerja Auditor}

Pshicological well being adalah sebuah kondisi individu yang memiliki sikap positif terhadap dirinya sendiri dan orang lain yang ditandai dengan adanya kemampuan membuat keputusan sendiri dan mengatur tingkah lakunya, menciptakan dan mengatur lingkungan yang sesuai dengan kebutuhannya, memiliki tujuan hidup dan membuat hidup lebih bermakna, serta berusaha mengeksplorasi dan mengembangkan dirinya (Ryff, 1995). Dengan demikian, individu yang memiliki psychological well being yang tinggi akan menyebabkan kinerja yang 
baik pula, demikian pula sebaliknya individu yang tidak memiliki psychological well being yang baik maka akan mudah tertekan dan dapat menyebabkan stress kerja. Adapun hipotesisnya sebagai berikut:

H2: Psychological Well Being berpengaruh positif terhadap kinerja auditor.

3. Pengaruh Self Efficacy terhadap Kinerja Auditor

Suprapta dan Setiawan (2017) menyatakan bahwa self efficacy merupakan kepercayaan seseorang terhadap kemampuannya untuk dapat melaksanakan tugas dengan baik. Individu yang memiliki tingkat self efficacy yang tinggi akan memiliki keyakinan dalam menjalankan tanggung jawab yang diembannya meskipun dalam kondisi yang sulit ataupun terdapat konflik peran didalamnya sehingga individu yang bersangkutan memiliki peluang keberhasilan yang lebih tinggi dibandingkan dengan orang yang pesimis terhadap pekerjaannya atau dalam hal ini memiliki nilai yang rendah dalam aspek self efficacy. Adapun hipotesisnya sebagai berikut:

H3: Self efficacy berpengaruh positif terhadap kinerja auditor.

4. Task Complexity Memoderasi Pengaruh Healty Lifestyle terhadap Kinerja Auditor

Danna dan Griffin (1999) mengartikan gaya hidup atau healty lifestyle sehat merupakan kebiasaan menjaga program olahraga fisik secara teratur, menjalankan diet seimbang, kebiasaan tidur yang baik, dan menahan diri dari konsumsi alkohol dan tembakau yang berlebih. Paramitha (2014) menambahkan individu yang memiliki mekanisme gaya hidup sehat cenderung memiliki ketahanan fisik dan psikis yang baik dibandingkan dengan individu yang tidak menerapkan gaya hidup sehat dalam kehidupan sehari-harinya sehingga dapat meminimalisir stress kerja yang ada. Kompleksitas tugas yang tinggi dengan angaran waktu yang terbatas dapat memperlemah hubungan antara healty lifestyle dengan kinerja auditor. Hal ini disebabkan karena penerapan pola hidup sehat hanya berperan dalam membuat auditor mendapatkan kebugaran yang baik sehingga bisa membuat auditor lebih siap dalam melaksanakan penugasan auditnya. Tingginya kompleksitas tugas yang melebihi kapasitas auditor akan menyebabkan auditor tetap memiliki kinerja yang tidak maksimal meskipun telah menerapkan gaya hidup sehat. Berbeda halnya ketika auditor memiliki tingkat kompleksitas tugas yang sesuai dengan kapasitasnya, penerapan pola hidup sehat akan membantu auditor untuk mendapatkan kinerja yang maksimal. Namun, auditor yang selalu menjaga independensinya akan selalu berupaya untuk tidak menurunkan kinerjanya meskipun mengalami tekanan tugas yang banyak sehingga memungkinkan untuk memilih alternatif yang bisa digunakan pada saat mendapatkan tugas yang kompleks. Dengan mendapatkan tugas yang kompleks auditor yang professional akan memilih opsi yang terbaik untuk tetap bugar. Dengan demikian, tingginya kompleksitas tugas dapat membuat auditor memilih gaya hidup sehat untuk diterapkan agar dapat selalu bugar dalam menjalankan penugasan auditnya. Adapun hipotesisnya sebagai berikut:

H4: Task complexity memoderasipengaruh healty lifestyle terhadap kinerja auditor.

5. Task Complexity memoderasi Pengaruh Psychological Well Beingterhadap kinerja auditor

Kristanto (2014) menunjukkan kesejahteraan psikologis (psychological well being) berpengaruh positif terhadap kinerja auditor. Didalam perusahaan atau kantor akuntan dapat mengalami stress kerja yang disebabkan oleh adanya ketidakjelasan, konflik, dan overload. 
Oleh karena itu, ketika kesejahteraan psikologi auditor baik akan berpengaruh terhadap kepuasan kerja auditor yang meningkat, sebaliknya ketika auditor mengalami stres kerja maka akan menyebabkan penurunan kinerjanya. Kompleksitas tugas yang terlalu tinggi yang dimiliki oleh auditor dapat menyebabkan peran kesejahteraan psikologis (psychological well being) terhadap kinerja auditor berkurang atau bahkan tidak ada.Psychological well being yang baik mampu memberikan rasa nyaman dalam auditor melaksanakan penugasan auditnya, akan tetapi bukan berarti akan menambahkan kompetensi auditor. Kompleksitas audit yang terlalu tinggi dapat membuat auditor kesulitan mendapatkan kinerja yang optimal meskipun dalam kondisi mental yang baik. Dengan demikian, tingginya kompleksitas tugas yang dibebankan kepada auditor dapat mengurangi dampak dari psychological well being terhadap kinerja auditor. adapun hipotesisnya sebagai berikut:

H5: Task complexity memoderasipengaruh psychological well being terhadap kinerja auditor.

6. Task Complexity memoderasi Pengaruh Psychological Well Beingterhadap kinerja auditor

Suprapta dan Setiawan (2017) menyatakan bahwa self efficacy merupakan kepercayaan seseorang terhadap kemampuannya untuk dapat melaksanakan tugas dengan baik. Seseorang yang memiliki tingkat self efficacy yang tinggi akan tetap menerima dan menjalankan tanggung jawab yang diterima tanpa membatasi diri meskipun terjadi konflik peran didalamnya, sebaliknya seseorang yang memiliki tingkat self efficacy yang rendah cenderung akan mengalami kegagalan karena adanya perselisihan harapan yang berkaitan dengan suatu peran (Muallifah dan Astuti, 2016). Peran self efficacy sangat dibutuhkan individu dalam memotivasi diri agar mampu menyelesaikan penugasan dengan baik. Namun, tingginya kompleksitas audit yang dialami oleh auditor dapat mengurangi hubungan antara self efficacy dengan kinerja auditor. Self efficacy dapat berperan dalam memberikan motivasi pada auditor agar dapat mengerjakan penugasan dengan baik. Tingginya kompleksitas tugas yang dibebankan kepada auditor dapat mengurangi peran self efficacy terhadap kinerja auditor.Self efficacy dapat berperan dalam memberikan motivasi bagi auditor dalam melaksanakan penugasan auditnya, akan tetapi bukan berarti akan menambah kemampuan auditor dalam menyelesaikan penugasan auditnya. Tingkat kompleksitas tugas yang tinggi melebihi kemampuan auditor akan berpotensi untuk menurunkan kinerja auditor meskipun memiliki kepercayaan diri yang tinggi. Adapun hipotesisnya sebagai berikut:

H6: Task complexity memoderasipengaruh self efficacy terhadap kinerja auditor.

\section{Metode Penelitian}

\subsection{Jenis dan Lokasi Penelitian}

Jenis penelitian yang digunakan pada penelitian ini adalah penelitian kuantitatif yang menggunakan pendekatan korelasi.Penelitian korelasi adalah suatu penelitian yang melibatkan tindakan pengumpulan data guna menentukan apakah ada hubungan dan tingkat hubungan antara dua variabel atau lebih.Lokasi penelitian ini dilakukan di Inspektorat Provinsi Sulawesi Selatan.

\subsection{Teknik Pengambilan Sampel}


Pengambilan sampel dalam penelitian ini dilakukan secara acak (probability sampling) dengan menggunakan teknik sampling acak sederhana (simple random sampling). Alasan penggunaan teknik simple random sampling adalah agar semua anggota dalam populasi memiliki peluang yang sama untuk mewakili populasi.Jumlah sampel dalam penelitian ini adalah sebanyak 31 responden yang bekerja di Inspektorat Provinsi Sulawesi Selatan. Auditor yang dijadikan sampel penelitian memiliki pengalaman kerja lebih dari dua tahun sebagai seorang auditor.

\subsection{Jenis dan Sumber Data}

Jenis data yang digunakan dalam penelitian ini adalah data kuantitatif. Sumber data yang digunakan pada penelitian ini adalah sumber data primer, yaitu data yang langsung dari sumber data penelitian yang diproses secara langsung dari sumber aslinya. Data primer dalam penilitian ini adalah tanggapan yang akan dijawab langsung oleh subjek penelitian melalui kuesioner.

\subsection{Teknik Analisis Data}

Teknik analisis data yang digunkan dalam penelitian ini adalah analisis regresi linear berganda, data diuji melalui uji kualitas data, uji asumsi klasik, dan juga pengujian hipotesis.Uji kualitas data dilakukan untuk memastikan kevalidan dan reliabilitas instrumen yang digunakan dalam penelitian.Uji asumsi klasik dilakukan untuk menentukan ketepatan model yang digunakan dalam penelitian. Uji hipotesis dilakukan untuk menentukan kebenaran hipotesis secara statistik dan menarik kesimpulan tentang penerimaan atau penolakan terhadap hipotesis yang akan diuji.

\subsection{Definisi Operasional}

Penelitian ini mengukur setiap variabeldengan menggunakan skala likert (likert scale) yang mengukur sikap dengan menyatakan setuju atau ketidaksetujuannya terhadap subjek, objek, atau kejadian tertentu. Skala ini menggunakan lima angka penilaian, yaitu: (1) sangat tidak setuju, (2) tidak setuju, (3) ragu-ragu atau netral, (4) setuju, (5) sangat setuju. Definisi operasional tersebut adalah sebagai berikut:

\section{Variabel Independen}

\section{a. Healty Lifestyle (X1)}

Danna dan Griffin (1999) mengartikan gaya hidup sehat atau healty lifestyle merupakan kebiasaan menjaga program olahraga fisik secara teratur, menjalankan diet seimbang, kebiasaan tidur yang baik, dan menahan diri dari konsumsi alkohol dan tembakau yang berlebihan. Safitri et, al (2014) mengemukakan empat dimensi gaya hidup sehat yakni: (1) pola makan; (2) olahraga teratur; (3) istrahat tidur; dan (4) pengendalian stress.

b. Psychological Well Being (X2)

Psycholological well being atau yang lebih dikenal dengan sebutan kesejahteraan psikologi adalah ukuran multidimensi dari perkembangan psikologis dan kesehatan mental, termasuk sklala tingkatan kemandirian dan hubungan positif dengan orang lain 
(Ryff, 1995). Psychological well being adalah sebuah kondisi individu yang memiliki sikap positif terhadap dirinya sendiri dan orang lain yang ditandai dengan adanya kemampuan membuat keputusan sendiri dan mengatur tingkah lakunya, menciptakan dan mengatur lingkungan yang sesuai dengan kebutuhannya, memiliki tujuan hidup dan membuat hidup lebih bermakna, serta berusaha mengeksplorasi dan mengembangkan dirinya (Ryff, 1995). Ryff (1995) mengemukakan enam dimensi psychological well being, yaitu: (1) penerimaan diri (self acceptance); (2) relasi positif dengan orang lain (positive relations with others);(3) autonomi (autonomy); (4) penguasaan lingkungan (environmental mastery); (5) tujuan hidup (purpose in life); dan (6) dimensi pertumbuhan pribadi (personal growth).

c. Self efficacy (X3)

Dewanto (2008) dalam istilah self efficacy termuat perilaku afektif perasaan, kepercayaan, dan keyakinan seseorang terhadap kemampuan dirinya.Suprapta dan Setiawan (2017) menyatakan bahwa self efficacy merupakan kepercayaan seseorang terhadap kemampuannya untuk dapat melaksanakan tugas dengan baik. Bandura (1997) menyatakan bahwa self efficacy memiliki tiga dimensi yaitu: (1) kesulitan tugas (Level/Magnitude); (2) kekuatan (strength); dan (3) variasi situasi (generality).

2. Variabel Dependen (Y)

Variabel dependen dalam penelitian ini adalah kinerja auditor.Trisaningsih (2007) menyatakan kinerja auditor adalah suatu hasil karya yang dicapai oleh seseorang dalam melaksanakan tugas-tugas yang dibebankan kepadanya yang didasarkan atas kecakapan, pengalaman, dan kesungguhan waktu yang diukur dengan mempertimbangkan kuantitas, kualitas, dan ketepatan waktu. Pendapat lain dikemukakan oleh Azhar (2013) yang menyatakan bahwa kinerja auditor adalah akuntan publik yang melaksanakan penugasan pemeriksaan (examination) secara objektif atas laporan keuangan suatu perusahaan atau organisasi lain dengan tujuan untuk menentukan laporan keuangan tersebut menyajikan secara wajar sesuai dengan prinsip akuntansi yang berlaku umum, dalam semua hal yang material, posisi keuangan dan hasil usaha perusahaan. Goldwasser (1993) mengemukakan tiga indikator kinerja auditor sebagai berikut: (1) kualitas kerja; (2) kuantitas kerja; dan ketepatan waktu.

\section{Variabel Moderasi (M)}

Variablel moderasi dalam penelitian ini adalah kompleksitas tugas atau task complexity.Task complexity merupakan tugas yang membingungkan dan sulit diukur secara objektif karena persepsi individu tentang kesulitan suatu tugas audit berbeda, tergantung dari individu tersebut merespon sulitnya tugas tersebut (Sanusi et, al, 2007). Jamilah et, al (2007) kompleksitas tugas adalah sulitnya suatu tugas yang disebabkan oleh terbatasnya kapabilitas, dan daya ingat serta kemampuan untuk mengintegrasikan masalah yang dimiliki oleh seorang pembuat keputusan. Boynton (2011: 54) terdiri dari beberapa indikator, yaitu: (1) tingkat kesulitan tugas audit; (2) struktur tugas; (3) banyaknya informasi yang tidak relevan; dan (4) adanya ambiguitas yang tinggi. 


\section{Hasil dan Pembahasan}

\subsection{UjiValiditas}

Uji Validitas adalah prosedur untuk memastikan valid atau tidaknya kuesioner yang akan digunakan untuk mengukur variabel penelitian. Untuk mengetahui item pernyataan itu valid dengan melihat nilai Corrected Item Total Corelation. Apabila item pernyataan mempunyai $\mathrm{r}$ hitung >dari tabel $\mathrm{r}$ maka dapat dikatakan valid. Pada penelitian ini terdapat jumlah sampel $(n)=31$ responden dan besarnya df dapat dihitung 31-2 $=29$ dengan $\mathrm{df}=29$ dan alpha $=0,05$ didapat tabel $r=0,3009$. Jadi, item pernyataan yang valid mempunyai $r$ hitung lebih besar dari 0,3009.

\subsection{Uji Reliabilitas}

Uji reliabilitas digunakan untuk mengukur suatau kuesioner yang merupakan indikator dari variabel atau konstruk. Suatu kuesioner dikatakan reliabel atau handal jika jawaban seseorang terhadap pernyataan adalah konsisten atau stabil dari waktu ke waktu. Uji reabilitas data dilakukan dengan menggunakan metode Cronbach Alpha yakni suatu instrument dikatakan reliable bila memiliki koefisien keandalan reabilitas sebesar 0,70 atau lebih. Dari hasil pengujian nilai cronbach's alpha dari semua variabel lebih besar dari 0,70, sehingga dapat disimpulkan bahwa instrumen kuesioner yang digunakan untuk menjelaskan variabel healty lifestyle, psychological well being, self efficacy,kinerja auditor dan task complexity handal atau dapat dipercaya sebagai alat ukur variabel.

\subsection{Uji Hipotesis}

Uji hipotesis dilakukan untuk menentukan kebenaran hipotesis secara statistik dan menarik kesimpulan tentang penerimaan atau penolakan terhadap hipotesis yang akan diuji.

\subsubsection{UjiKoefisien Determinasi}

Uji koefisien determinasi dilakukan untuk mengetahui sebarapa besar pengaruh variabel bebas terhadap variabel terikatnya (Ghozali, 2013). $\mathrm{R}^{\wedge} 2$ (Adjusted RSquare) dari model regresi digunakan untuk mengetahui seberapa besar kemampuan variabel bebas (independen) dalam menerangkan variabel terikat (dependen).

Tabel 4.3

\section{Hasil Uji Koefisien Determinasi $\left(\mathbf{R}^{2}\right)$}

\begin{tabular}{lcccc}
\hline & \multicolumn{4}{c}{ Model Summary } \\
Model & $\mathrm{R}$ & $\mathrm{R}$ & Adjusted R & Std. Error of the Estimate \\
& & Square & Square & 1.790 \\
1 & $.766^{\mathrm{a}}$ & .587 & .541 & 1 \\
\hline $\begin{array}{l}\text { a. Predictors: (Constant), Self efficacy, Healty lifestyle, Psychological well } \\
\text { being }\end{array}$
\end{tabular}




\section{Sumber: Output SPSS 20 (2019)}

Dari tabel 4.3di atas diketahui bahwa nilai R2 sebesar 0,541, hal ini berarti bahwa $54,1 \%$ variabel kinerja auditor dipengaruhi oleh variabel healty lifestyle, psychological well being, dan self efficacy dan sisanya sebesar $45,9 \%$ dipengaruhi oleh faktor lain yang tidak dijelaskan dalam penelitian ini.

\subsubsection{Uji Simultan}

Uji simultan dilakukan untuk mengetahui apakah ada pengaruh variabel independen secara simultan atau bersama-sama terhadap variabel independen.

\section{Tabel 4.4}

\section{Hasil Uji f - Uji Simultan}

\begin{tabular}{|c|c|c|c|c|c|c|}
\hline \multicolumn{7}{|c|}{ ANOVA $^{a}$} \\
\hline \multicolumn{2}{|c|}{ Model } & $\begin{array}{l}\text { Sum of } \\
\text { Squares }\end{array}$ & Df & $\begin{array}{l}\text { Mean } \\
\text { Square }\end{array}$ & $\mathrm{f}$ & Sig. \\
\hline \multirow[t]{3}{*}{1} & $\begin{array}{l}\text { Regressi } \\
\text { on }\end{array}$ & 122.812 & 3 & 40.937 & 12.772 & $.000^{\mathrm{b}}$ \\
\hline & Residual & 86.542 & 27 & 3.205 & & \\
\hline & Total & 209.355 & 30 & & & \\
\hline \multicolumn{7}{|c|}{ a. Dependent Variable: Kinerja auditor } \\
\hline \multicolumn{7}{|c|}{$\begin{array}{l}\text { b. Predictors: (Constant), Self efficacy, Healty lifestyle, Psychological well } \\
\text { being }\end{array}$} \\
\hline
\end{tabular}

Sumber: Output SPSS 20 (2019)

Berdasarkan tabel 4.4 dapat dilihat bahwa dalam pengujian regresi berganda menunjukkan hasil $\mathrm{f}$ hitung sebesar 12,772 dengan tingkat signifikasi 0,000 lebih kecil dari 0,05, dimana f hitung 12,772 lebih dari nilai f tabelnya yakni sebesar 2,95 (df1=3 df2=28). Dengan demikian dapat disimpulkan bahwa variabel healty lifestyle, psychological well being, dan self efficacy bersama-sama berpengaruh terhadap kinerja auditor.

\subsubsection{Uji Parsial}

Uji parsial digunakan untuk mengetahui apakah ada pengaruh secara parsial atau sendiri-sendiri variabel independen terhadap variabel dependennya. Hasil uji parsial dapat dilihat dalam tabel berikut: 
Tabel 4.5

Hasil Uji t - Uji Parsial

\begin{tabular}{|c|c|c|c|c|c|c|}
\hline \multicolumn{7}{|c|}{ Coefficients $^{\mathrm{a}}$} \\
\hline \multirow{2}{*}{\multicolumn{2}{|c|}{ Model }} & \multicolumn{2}{|c|}{$\begin{array}{c}\text { Unstandardized } \\
\text { Coefficients }\end{array}$} & \multirow{3}{*}{$\begin{array}{c}\text { Standardize } \\
\mathrm{d} \\
\text { Coefficient } \\
\text { s } \\
\text { Beta }\end{array}$} & \multirow[t]{2}{*}{$\mathrm{t}$} & \multirow[t]{2}{*}{ Sig. } \\
\hline & & B & Std. Error & & & \\
\hline \multirow[t]{4}{*}{1} & (Constant) & -2.918 & 4.911 & & -.594 & .557 \\
\hline & $\begin{array}{l}\text { Healty } \\
\text { lifestyle }\end{array}$ & .336 & .148 & .335 & 2.265 & .032 \\
\hline & $\begin{array}{l}\text { Psychologic } \\
\text { al well } \\
\text { being }\end{array}$ & .093 & .167 & .090 & .559 & .581 \\
\hline & Self efficacy & .728 & .186 & .543 & 3.912 & .001 \\
\hline
\end{tabular}

Sumber: Output SPSS 20 (2019)

Hasil interpretasi atas hipotesis penelitian ( $\mathrm{H} 1, \mathrm{H} 2$ dan $\mathrm{H} 3)$ yang diajukan dapat dilihat sebagai berikut:

a. Healty lifestyle berpengaruh positif dan signifikan terhadap kinerja auditor.

Berdasarkan tabel 4.5 dapat dilihat bahwa variabel healty lifestyle memiliki t hitung sebesar 2,265 < tabel t sebesar 2.04841 (sig. $\alpha=0,05$ dan df =28) dengan koefisien beta unstandardized sebesar 0,336 dan tingkat signifikasi 0,032 yang lebih kecil dari 0,05, maka H1 diterima. Hal ini berarti healty lifestyle berpengaruh positif terhadap kinerja auditor.

b. Psychological well being berpengaruh positif terhadap kinerja auditor.

Berdasarkan tabel 4.5 dapat dilihat bahwa variabel psychological well being memiliki thitung sebesar $0,581<$ tabel t sebesar 2.04841 (sig. $\alpha=0,05$ dan $\mathrm{df}=28$ ) dengan koefisien beta unstandardized sebesar 0,093 dan tingkat signifikasi 0,581 yang lebih besar dari 0,05, maka H2 ditolak. Hal ini berarti psychological well being tidak berpengaruh terhadap kinerja auditor.

c. Self efficacy berpengaruh positif terhadap kinerja auditor.

Berdasarkan tabel 4.5 dapat dilihat bahwa variabel self efficacy memiliki t hitung sebesar $6,082>$ tabel t sebesar 2.04841 (sig. $\alpha=0,05$ dan $\mathrm{df}=28$ ) dengan koefisien beta unstandardized sebesar 0,728 dan tingkat signifikasi 0,001 yang lebih kecil dari 0,05, maka $\mathrm{H} 3$ diterima. Hal ini berarti self efficacy berpengaruh positif terhadap kinerja auditor.

\subsection{Uji Regresi Moderasi dengan Pendekatan Uji Interkasi}

\subsubsection{Uji Koefisien Determinasi}


Uji koefisien determinasi dilakukan untuk mengetahui sebarapa besar pengaruh variabel bebas terhadap variabel terikatnya (Ghozali, 2013). $\mathrm{R}^{\wedge} 2$ (Adjusted RSquare) dari model regresi digunakan untuk mengetahui seberapa besar kemampuan variabel bebas (independen) dalam menerangkan variabel terikat (dependen).

Tabel 4.6

Hasil Uji Koefisien Determinasi $\left(\mathbf{R}^{2}\right)$

\begin{tabular}{|c|c|c|c|c|}
\hline \multicolumn{5}{|c|}{ Model Summary } \\
\hline Model & $\mathrm{R}$ & $\begin{array}{c}\mathrm{R} \\
\text { Square }\end{array}$ & $\begin{array}{l}\text { Adjusted R } \\
\text { Square }\end{array}$ & Std. Error of the Estimate \\
\hline 1 & $.817^{\mathrm{a}}$ & .667 & .566 & 1.740 \\
\hline \multicolumn{5}{|c|}{$\begin{array}{l}\text { a. Predictors: (Constant), Total_X3.M, Total_X1, Total_X3, Total_X2, } \\
\text { Total_M, Total_X1.M, Total_X2.M }\end{array}$} \\
\hline
\end{tabular}

Sumber: Output SPSS 20 (2019)

Berdasarkan tabel 4.6di atas dapat dilihat bahwa nilai $\mathrm{R}^{\wedge} 2$ (Adjusted R Square) sebesar 0,566, hal ini berarti bahwa 56,6\% variabel kinerja auditor dipengaruhi oleh variabel healty lifestyle, psychological well being, dan self efficacy yang dimoderasi oleh task complexity dan sisanya sebesar $43,4 \%$ dipengaruhi oleh faktor lain yang tidak dijelaskan dalam penelitian ini.

\subsubsection{Uji Simultan}

Uji simultan dilakukan untuk mengetahui apakah ada pengaruh variabel independen secara simultan atau bersama-sama terhadap variabel independen.

Tabel 4.7

Hasil Uji F- Uji Simultan

\begin{tabular}{|c|c|c|c|c|c|}
\hline \multicolumn{6}{|c|}{ ANOVA $^{a}$} \\
\hline Model & $\begin{array}{l}\text { Sum of } \\
\text { Squares }\end{array}$ & Df & $\begin{array}{l}\text { Mean } \\
\text { Square }\end{array}$ & $\mathrm{f}$ & Sig. \\
\hline $\begin{array}{l}1 \text { Regressi } \\
\text { on }\end{array}$ & 139.682 & 7 & 19.955 & 6.587 & $.000^{\mathrm{b}}$ \\
\hline Residual & 69.673 & 23 & 3.029 & & \\
\hline Total & 209.355 & 30 & & & \\
\hline \multicolumn{6}{|c|}{ a. Dependent Variable: Total_Y } \\
\hline \multicolumn{6}{|c|}{$\begin{array}{l}\text { b. Predictors: (Constant), Total_X3.M, Total_X1, Total_X3, Total_X2, } \\
\text { Total_M, Total_X1.M, Total_X2.M }\end{array}$} \\
\hline
\end{tabular}

Berdasarkan tabel 4.7 dapat dilihat bahwa nilai f hitung sebesar 6,587 dengan tingkat signifikasi 0,000 lebih kecil dari 0,05, dimana $\mathrm{f}$ hitung senilai 6,587 lebih dari nilai tabel $\mathrm{f}$ sebesar 2,95 (sig. $\alpha=0,05$ dan $\mathrm{df}=28$ ). Hal ini menunjukkan bahwa variabel healty lifestyle, 
psychological well being, dan self efficacy secara simultan berpengaruh terhadap kinerja auditor.

\subsubsection{Uji Parsial}

Uji parsial digunakan untuk mengetahui apakah ada pengaruh secara parsial atau sendiri-sendiri variabel independen terhadap variabel dependennya. Hasil uji parsial dapat dilihat dalam tabel berikut:

Tabel 4.8

Hasil Uji t - Uji Parsial

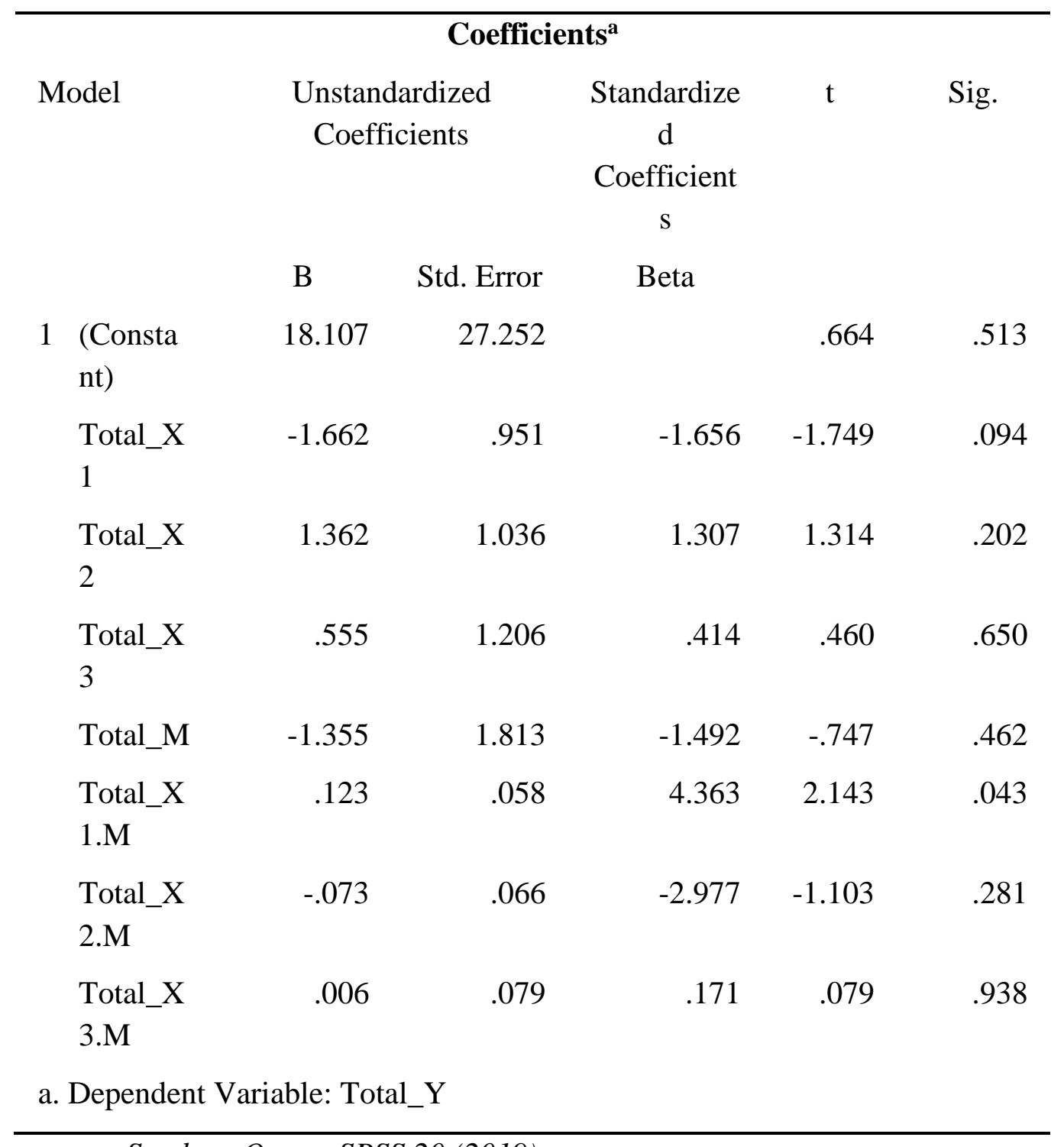

Sumber: Output SPSS 20 (2019)

Berdasarkan tabel 4.8 hasil interpretasi dan pembahasan atas hipotesis penelitian $\left(\mathrm{H}_{4}\right.$, $\mathrm{H}_{5}$ dan $\mathrm{H}_{6}$ ) dapat dilihat sebagai berikut:

a. Task complexity memoderasi pengaruh healty lifestyle terhadap kinerja auditor 
Dari hasil uji MRA yang terlihat pada tabel 4.8 menunjukkan bahwa variabel moderating X1.M mempunyai t hitung sebesar 2.143 lebih besar dari t tabel sebesar 2.04841 dengan koefisien understandardized sebesar 0,123 dan tingkat signifikansi 0,043 yang lebih kecil dari 0,05, maka hipotesis keempat diterima. Hal ini menunjukkan bahwa task complexity mampu memoderasi hubungan antara healty lifestyle terhadap kinerja auditor. Jadi hipotesis keempat yang diajukan dalam penelitian ini diterima.

b. Task complexity memoderasi pengaruh psychological well being terhadap kinerja aditor

Dari hasil uji MRA yang terlihat pada tabel 4.8 menunjukkan bahwa variabel moderating X1.M mempunyai t hitung sebesar (-1.103) lebih kecil dari t tabel sebesar 2.04841 dengan koefisien understandardized sebesar $(-0,281)$ dan tingkat signifikansi 0,281 yang lebih besar dari 0,05, maka hipotesis keempat ditolak. Hal ini menunjukkan bahwa task complexity tidak mampu memoderasi hubungan antara healty lifestyle terhadap kinerja auditor. Jadi hipotesis kelima yang diajukan dalam penelitian ini ditolak.

c. Task complexity memoderasi pengaruh self efficacy terhadap kinerja aditor

Dari hasil uji MRA yang terlihat pada tabel 4.8 menunjukkan bahwa variabel moderating X1.M mempunyai t hitung sebesar 0,79 lebih kecil dari t tabel sebesar 2.04841 dengan koefisien understandardized sebesar 0,006 dan tingkat signifikansi 0,938 yang lebih besar dari 0,05, maka hipotesis keenam ditolak. Hal ini menunjukkan bahwa task complexity tidak mampu memoderasi hubungan antara self efficacy terhadap kinerja auditor. Jadi hipotesis keenam yang diajukan dalam penelitian ini ditolak.

\subsection{Pembahasan}

Pengaruh healty lifestyle terhadap kinerja auditor.Berdasarkan uji regresi di atas menunjukkan bahwa variabel healty lifestyle berpengaruh positif dan signifikan terhadap kinerja auditor. Auditor yang menjalankan gaya hidup sehat yang baik akan memberikan kebugaran dan meningkatkan stamina serta daya tahan tubuh yang baik pula sehingga akan membuat kinerja auditor menjadi lebih baik. Hal ini sejalan dengan teori atribusi yang menjelaskan alasan seseorang memilih suatu tindakan dalam upaya untuk mengatasi masalah yang dihadapi. Teori atribusi adalah teori yang menjelaskan upaya untuk memahami penyebab dibalik perilaku orang lain (Rahmi dan Sofia, 2017). Teori atribusi menjelaskan alasan auditor memilih untuk menerapkan gaya hidup sehat adalah agar kebugaran dan stamina yang dimiliki oleh auditor tetap prima sehinggga kinerjanya tetap baik meskipun dalam kondisi yang sulit. Hasil penelitian ini sejalan dengan penelitian yang dilakukan oleh Paramitha (2014) mengurangi stress kerja individual sehingga dapat meminimalisir turn over intentions. Namun penelitian ini tidak sejalan dengan penelitian yang dilakukan oleh Merawati dan Prayati (2017) dan Kristanto et, al (2014) yang menjelaskan bahwa healty lifestyle tidak berpengaruh terhadap kinerja auditor.

Pengaruh psychological well being terhadap kinerja auditor.Berdasarkan uji regresi di atas menunjukkan bahwa variabel psychological well being berpengaruh positif dan signifikan terhadap kinerja auditor. Hal ini terjadi karena profesi seorang auditor cenderung mengalami kompleksitas tugas yang tinggi sehingga memiliki nilai yang rendah terhadap psychological 
well being yang dimiliki. Kompleksitas tugas yang tinggi membuat auditor tidak berpikir untuk menciptakan kondisi nyaman yang sesuai dengan keinginannya sehingga auditor sering mengabaikan kondisi psikologi yang baik.Auditor akan lebih memilih untuk mengembangkan kompetensinya agar tidak tertinggal dari perkembangan standar-standar yang berubah sangat dinamis sehingga akan lebih memilih untuk menyibukkan diri dengan melakukan pelatihan profesi untuk meningkatkan kinerjanya dibandingkan mencari kesenanangan batin dengan berlibur untuk mendapatkan psikologi yang baik. Dengan demikian, psychological well being tidak mampu mempengaruhi kinerja auditor. Penelitian ini tidak sejalan denganpenelitian dari Kristanto et, al (2014) yang menyatakan bahwa psychological well being berpengaruh positif terhadap kinerja auditor. Hasil penelitiannya, menunjukkan bahwa didalam perusahaan atau kantor akuntan dapat mengalami stress kerja yang disebabkan oleh adanya ketidakjelasan, konflik, dan overload. Oleh karena itu, ketika kesejahteraan psikologi auditor baik akan berpengaruh terhadap kepuasan kerja auditor yang meningkat, sebaliknya ketika auditor mengalami stress kerja maka akan menyebabkan penurunan kinerjanya.

Pengaruh self efficacy terhadap kinerja auditor.Berdasarkan uji regresi di atas menunjukkan bahwa variabel self efficacy berpengaruh positif dan signifikan terhadap kinerja auditor.Auditor yang memiliki kepercayaan diri yang tinggi akan dapat mengembangkan kepribadian yang kuat, mengurangi stress, tidak mudah terpengaruh sehingga berpengaruh terhadap peningkatan kinerjanya. Hal ini sejalan dengan teori pengharapan (expectancy theory) yang menyatakan bahwa intensitas cenderung melakukan sesuatu dengan harapan bahwa kinerja akan diikuti dengan hasil yang pasti dan daya tarik setiap individu. Auditor yang memiliki tingkat efikasi yang tinggi akan memiliki harapan yang kuat untuk bisa menyelesaikan tugasnya dengan baik sehingga akan berpengaruh pada peningkatan kinerjanya. Sebaliknya, auditor yang tidak memiliki efikasi yang tinggi akan mudah menyerah pada saat mendapatkan kompleksitas tugas yang tinggi sehingga akan berpengaruh buruk pada kinerjanya.Penelitian ini sejalan dengan hasil penelitian Suprapta dan Setiawan (2017) dan Kristianti (2015) yang menyatakan bahwa self efficacy berpengaruh positif terhadap kinerja auditor. Namun, hasil penelitian ini tidak sejalan dengan penelitian yang dilakukan oleh Gasendi et, al (2008) yang menyatakan bahwa self efficacy berpengaruh negatif dan signifikan terhadap kinerja auditor.

Pengaruh task complexity dalam memoderasi pengaruh antara healty lifestyle terhadap kinerja auditor. Auditor professional yang dibebankan tugas yang tinggi tidak membuatnya menurunkan kinerjanya,akan tetapi memilih alternatif yang tepat untuk digunakan dalam situasi tugas yang kompleks. Auditor professional tidak menjadikan tugas sebagai alasan untuk menggurangi kinerjanya,akan tetapi menjadikan itu tantangan yang dapat menambah pengalaman serta mengembangkan kompetensinya dalam menghadapi kondisi sulit yang ada. Auditor yang memiliki tugas yang kompleks harus selalu menjaga kebugarannya sehingga perlu untuk menerapkan gaya hidup sehat agar selalu prima dalam menjalankan penugasan auditnya. Dengan demikian, tingginya kompleksitas tugas yang dihadapi oleh auditor memperkuat hubungan antara gaya hidup sehat terhadap kinerja auditor.

Pengaruh task complexity dalam memoderasi pengaruh antara psychological well being terhadap kinerja auditor. Berdasarkan uji regresi di atas menunjukkan bahwa task 
complexity tidak dapat memoderasi hubungan antara psychological well being terhadap kinerja auditor. Kesejahteraan psikologi yang dimiliki oleh auditor akan menuntun pada kenyamanan dan motivasi dalam bekerja sehingga auditor tidak akan merasa tertekan dalam melaksanakan penugasan auditnya, namun bukan berarti dapat menambah kinerjanya. Dalam menjaga kompetensinya, auditor yang profesional tidak akan membiarkan kinerjanya menurun meskipun mengalami kompleksitas tugas yang sangat tinggi. Dengan demikian, kompleksitas tugas tidak mampu mengurangi pengaruh antara psychological well being terhadap kinerja auditor.

Pengaruh task complexity dalam memoderasi pengaruh antara self efficacyterhadap kinerja auditor.Berdasarkan uji regresi di atas menunjukkan bahwa task complexity tidak dapat memoderasi hubungan antara self efficacy terhadap kinerja auditor. Tingkat kompleksitas tugas yang tinggi melebihi kemampuan auditor akan berpotensi untuk menurunkan kinerja auditor meskipun memiliki kepercayaan diri yang tinggi. Akan tetapi, auditor yang professional tidak akan menurunkan kinerja yang dimilikinya meskipun dalam tekanan tugas yang tinggi. Auditor yang memiliki tingkat kepercayaan diri yang tinggi merasa mampu untuk mengatasi setiap masalah yang dihadapi bahkan menjadikan kompleksitas tugas yang tinggi sebagai tantangan yang bisa menambah kompetensinya. Dengan demikian, kompleksitas tugas tidak mampu mengurangi pengaruh self efficacy terhadap kinerja auditor.

\section{Kesimpulan, Implikasi, dan Keterbatasan}

\subsection{Kesimpulan}

Dari pembahasan di atas dapat disimpulkan sebagai berikut:

Healty lifestyle berpengaruh positif dan signifikan terhadap kinerja auditor.Healty lifestyle dapat berperan dalam memberikan kebugaran dan stamina yang prima bagi para auditor sehingga auditor bisa lebih siap dalam menjalankan tugas auditnya sehingga berpengaruh terhadap peningkatan kinerjanya.

Psychological well being tidak berpengaruh terhadap kinerja auditor. Auditor cenderung menghadapi kompleksitas tugas yang tinggi sehingga mengakibatkan auditor sulit menciptakan lingkungan kerja sesuai dengan yang diinginkannya. Dengan demikian, auditor menganggap Psychological well being tidak terlalu berpengaruh terhadap kinerja auditor.

Self efficacy berpengaruh positif dan signifikan terhadap kinerja auditor.Auditor yang memiliki self efficacy yang tinggi dapat berperan dalam memberikan motivasi dan mengembangkan kepribadian yang kuat, mengurangi stress, tidak mudah terpengaruh sehingga berpengaruh terhadap peningkatan kinerjanya.

Task complexity mampu memoderasi hubungan antara healty lifestyle terhadap kinerja auditor. Auditor professional yang dibebankan tugas yang tinggi tidak membuatnya menurunkan kinerjanya akan tetapi memilih alternatif yang tepat untuk digunakan dalam situasi tugas yang kompleks. Auditor harus selalu memperhatikan gaya hidup sehatnya agar dapat mengatasi kompleksitas tugas yang tinggi.

Task complexity tidak mampu memoderasi hubungan antara psychological well being terhadap kinerja auditor. Auditor menyadari bahwa profesi seorang auditor cenderung dengan kompleksitas tugas yang sangat tinggi, akibatnya auditor harus terbiasa dengan hal tersebut. 
Dengan demikian, tingginya task complexity tidak mengurangi pengaruh psychological well beingterhadap kinerja auditor.

Task complexity tidak mampu memoderasi hubungan antara self efficacy terhadap kinerja auditor. Auditor yang memiliki tingkat kepercayaan diri yang tinggi merasa mampu untuk mengatasi setiap masalah yang dihadapi bahkan menjadikan kompleksitas tugas yang tinggi sebagai tantangan yang bisa menambah kompetensinya. Dengan demikian, kompleksitas tugas tidak mampu mengurangi pengaruh self efficacy terhadap kinerja auditor.

\subsubsection{Implikasi}

Penerapan gaya hidup sehat sangat penting bagi auditor agar selalu mendapatkan kebugaran dalam menjalankan tugasnya sehingga hasil kerjanya dapat optimal. Oleh karena itu, auditor perlu memperhatikan pola hidup sehat dengan menjaga pola makan yang baik, mengurangi konsumsi alkohol yang berlebih, serta memiliki jam tidur yang cukup agar dapat tetap bugar dalam menjalankan aktivitasnya. Kompleksitas tugas yang tinggi akan berpotensi untuk membuat auditor menghabiskan banyak waktu sehingga sulit bagi auditor untuk sekedar menerpakan pola hidup sehat. Dengan demikian, auditor perlu untuk mencari alternatif yang tepat agar bisa menerapkan pola hidup sehat dalam pelaksanaan auditnya.

Selain penerapan gaya hidup sehat, auditor juga harus memiliki kepercayaan diri yang baik sehingga senantiasa bersikap optimis dalam segala kondisi. Dalam kondisi tekanan kompleksitas tugas yang tinggi, auditor seyogianya memiliki kepercayaan diri yang tinggi dan perencanaan yang matang agar dapat menghasilkan pemeriksaan yang optimal meskipun dalam keadaan kompleksitas tugas yang tinggi.

\subsection{Keterbatasan dan Saran}

Penelitian ini hanya berfokus pada faktor-faktor yang bisa membantu auditor lebih siap dalam melakukan penugasan auditnya shingga bisa meminimalisir kesalahan. Variabel yang digunakan dalam penelitian ini terbatas pada healty lifestyle, psychological well being, dan self efficacy yang merupakan faktor pembantu auditor agar lebih siap dalam menjalankan penugasan auditnya. Sampel yang digunakan dalam penelitian ini juga hanya berfokus pada auditor yang bekerja di kantor inspektorat provinsi Sulawesi selatan. Untuk itu penelitian selanjutnya disarankan menggunakan variabel lainnya di samping juga memperluas wilayah yang diteliti.Bagi penelitian selanjutnya diharapkan dapat mengamati variabel lainnya yang dapat berhubungan dengan eksternal auditor.Beberapa variabel tersebut adalah kompetensi, dan juga pengalaman auditor yang diduga dapat berpengaruh terhadap kinerja auditor.

\section{Referensi}

Azhar L, Al. 2013. Pengaruh Konflik Peran, Ketidakjelasan Peran, Kesan Ketidakpastian Lingkungan, Locus of Control, dan Motivasi Kerja terhadap Kinerja Auditor (Studi Empiris pada Kantor Akuntan Publik di Pekanbaru, Padang dan Batam). Jurnal Ekonomi, 21(4): 1-15.

Bandura, A. Self efficacy: The Exercise of Control. USA: WH Freeman and Company, 1997.

Boynton, William C., Raymon N. Johnson, dan Walter G. Kell. Modern Auditing Edisi ketujuh Jilid dua. Jakarta: Erlangga, 2011. 
Danna, Karen dan Ricky W. Griffin. 1999. Health and well-being in the workplace: A review and synthesis of the literature. Journal of Management,25(3): 357-384.

Dewanto, Stanley P. 2008. Peranan Kemampuan Akademik Awal, Self-Efficacy, dan Variabel Nonkognitif Lain Terhadap Pencapaian Kemampuan Representasi Multipel Matematis Mahasiswa Melalui Pembelajaran Berbasis Masalah. Educationist, 2(2): 123-133.

Futri, Putu Septiani dan Gede Juliarsa. 2014. Pengaruh Independensi, Profesionalisme, Tingkat Pendidikan, Etika Profesi, Pengalaman, dan Kepuasan Kerja Auditor pada Kualitas Audit Kantor Akuntan Publik di Bali. E-jurnal AkuntansiUniversitas Udayana, 7(2): 444-461.

Ghozali, Imam. Aplikasi Analisis Multivariat dengan Program IBM SPSS 21.Edisi ketujuh.Semarang : Universitas Diponegoro, 2013.

Goldwasser, D.L. 1993. The Plaintiffs's Bar Discusses Auditor Performance. The CPA Journal, 63(10): 48-52.

Hanif, Rheny Afriana. 2013. Pengaruh Struktur Audit, Konflik Peran, dan Ketidakjelasan Peran terhadap Kinerja Auditor. Jurnal Ekonomi, 21(3): 1-15.

Kristanto, Septian Bayu., Yunita Wijayanti, Marsella, Steffi Djayadi, Cristian Linus, dan Nova Christiana. 2014. Dampak Penerapan Gaya Hidup Sehat sebagai Upaya Menanggulangi Stress Kerja pada Auditor. Simposium Riset Ekonomi VI, 856-866.

Muallifah Masrurul dan Isthofaina Astuty.2016. Pengaruh Konflik Peran terhadap Kinerja dengan Self efficacy sebagai Variabel Moderasi. 7(2): 210-217.

Paramitha, Novena Mayayu. 2014. Pengaruh Gaya Hidup Sehat untuk Mengatasi Turnover Intentions yang terjadi di Akuntan Publik. Jurnal Akuntansi Bisnis, 13(25): 83-93.

Rahmi, Febri dan Asni Sovia. 2017. Dampak Sistem Pengendalian Internal, Perilaku Tidak Etis dan Moralitas Manajemen terhadap Kecenderungan Kecurangan Akuntansi pada Perusahaan Developer di Pekanbaru. Jurnal Al-Iqtishad, 13(1): 48-66.

Restuningdiah, Nurika dan Nur Indriantoro.2000. Pengaruh Partisipasi terhadap Kepuasan Pemakai dalam Pengembangan Sistem Informasi dengan Kompleksitas Tugas, Kompleksitas Sistem, dan Pengaruh Pemakai sebagai Moderating Variable.Jurnal Riset Akuntansi Indonesia, 3(2): 119-133.

Riff, Caroll D dan Corey Lee M. Keyes. 1995. The Structure of Psychological Well Being Revisted. Journal of Personality and Special Psychology, 69(4): 719-727.

Rimper, Rinna Ribka dan Lotje Kawet.2014. Pengaruh Perencanaan Karir dan Self efficacy terhadap Kinerja Karyawan pada PT PLN Persero Area Manado.Jurnal EMBA, 2(4): 413-423.

Singgih, Elisha Muliani dan Icuk Rangga Bawono. 2010. Pengaruh Independensi, Pengalaman, Due professional care dan Akuntabilitas terhadap Kualitas Audit (Studi pada Auditor di KAP "Big Four” Di Indonesia). Simposium nasional akuntansi XIII purwokerto, 1-24. 
Suprapta, Kadek Ricky Ardie dan Putu Ery Setiawan. 2017. Pengaruh Beban Kerja, Kepuasan Kerja, Self efficacy, dan Time Budget Pressure pada Kinerja Auditor. E Jurnal Akuntansi Universitas Udayana, 81-108.

Trinaninngsih, Sri. 2007. Independensi Auditor dan komitmen Organisasi sebagai mediasi pengaruh pemahaman Good Governance, Gaya kepemimpinan dan budaya organisasi terhadap kinerja Auditor.Prosiding Simposium Nasional Akuntansi X, 1-56.

Utami, Elisabeth Lasmira dan Retno Triani. 2015. Gambaran Tingkat Motivasi Kerja Karyawan PT. TOS dengan menggunakan Metode Expectancy Theory. Jurnal Ilmiah Psikologi Manasah, 4(1): 14-19.

Wicaksono, Aditya Pandu dan Dekar Urumsah.2016. Faktor Imfluencing Employes to Commit Fraud in Work Place Empirical Study in Indonesian Hospital.Asia Pacific Fraud Journal, 1(1): 1-18.

Wilopo.2006. Analisis Faktor-faktor yang Berpengaruh terhadap Kecenderungan Kecurangan Akuntansi: Studi pada Perusahaan Publik dan Badan Usaha Milik Negara di Indonesia. The Indonesian Journal of Accounting Research, 9(3).

Yurmaini.2017. Kecurangan Akuntansi (Fraud Accounting) dalam Perspektif Islam.Jurnal Akuntansi dan Bisnis, 93-104.

Copyright (c) 2020 Fahrun Rijal, Muhammad Wahyuddin Abdullah 